\title{
Hydrospire morphology and implications for blastoid phylogeny
}

\author{
Jennifer E. Bauer, ${ }^{1}$ Colin D. Sumrall, ${ }^{1}$ and Johnny A. Waters ${ }^{2}$ \\ ${ }^{1}$ Department of Earth and Planetary Sciences, 1412 Circle Dr., 306 EPS, University of Tennessee, Knoxville, Tennessee, 37996-1410, USA \\ 〈jbauer5@vols.utk.edu〉, 〈csumrall@utk.edu〉 \\ ${ }^{2}$ Department of Geology, Appalachian State University, Boone, North Carolina, 28608, USA 〈watersja@appstate.edu〉
}

\begin{abstract}
The external expression of hydrospires in blastoids has provided a basis for major and minor group classification in the clade for over a century. Unfortunately, the complete anatomy of the hydrospires has never been comprehensively studied. This study examined and described the internal hydrospires of six spiraculate species by digitally extracting hydrospire data from a legacy data set of serial acetate peels. Although only six models have been currently generated, hydrospire morphology is variable both within and between previously described spiraculate families. Hydrospires were found to possess novel characters that were incorporated into a phylogenetic analysis of the six digitally modeled species and several related species. The addition of internal morphology into the phylogenetic analysis provides further resolution between groupings of blastoids.
\end{abstract}

\section{Introduction}

Present understanding of blastoid phylogeny is insufficient. The current phylogenetic hypothesis does not include sufficient taxa to make robust interpretations of the evolutionary relationships among previously described groupings or even to verify their monophyly. External character data for blastoids have been accumulating for nearly 200 years and have been used over the past several decades in a variety of morphometric- and phylogenetic-based analyses (Foote, 1991; Waters and Horowitz, 1993; Bodenbender, 1995; Bodenbender and Fisher, 2001; Atwood and Sumrall, 2012; Sumrall and Waters, 2012; Atwood, 2013). A recent study by Atwood (2013) generated a phylogenetic framework to describe the synapomorphies and subclade relationships among blastoids. Unfortunately, our understanding of internal morphology is poor, and consequently, internal character data (with the exception of number of hydrospires) have been largely ignored, limiting character evidence of phylogenetic relationships.

Respiratory structures of blastozoan echinoderms are utilized as synapomorphies for clades and often are used to delineate species. Endothecal respiratory structures such as blastoid hydrospires, parablastoid cataspires, and dichopores of both glyptocystitoids and hemicosmitids are lightly calcified and typically well preserved in specimens with complete thecae (Paul, 1968; Sprinkle, 1973; Sprinkle and Sumrall, 2008; Sumrall and Waters, 2012). These structures can be examined by serially sectioning specimens (Beaver et al., 1967; Breimer, 1988a, b; Dexter et al., 2009; Schmidtling and Marshall, 2010) or in some cases through X-ray computed tomography (Rahman and Zamora, 2009; Waters et al., 2014; Rahman et al., 2015). This study focuses on examining the internal respiratory hydrospires of Blastoidea to provide additional character data for subsequent phylogenetic analysis.
Echinoderm homology.-Blastoidea is a diverse clade of Paleozoic stemmed echinoderms with a highly conservative body construction. Unlike many Paleozoic blastozoan echinoderms with irregular plating, blastoid thecal plating consists of 18-21 stable plates that are identifiable among all individuals within the clade. A wide variety of thecal shapes are identified in different blastoid clades (Beaver, 1967), and determining which plates form these morphologies provides a well-constrained framework to understanding the evolution of morphology in the clade. Blastoids are a long-lived clade, extending from the Late Ordovician to the late Permian, providing an opportunity to examine morphological and evolutionary patterns through time (Foote, 1991).

Reconciling blastoid morphologies with those of other blastozoans has been difficult because the morphologies of blastoids are unusually derived and the terminology applied is unique to the clade (Sumrall and Waters, 2012; Kammer et al., 2013). The universal elemental homology (UEH) model (Sumrall, 2010; Sumrall and Waters, 2012) for classifying homologous elements of the oral area and ambulacra among blastozoans provides a theoretical framework for understanding element homology in extinct echinoderms and reduces confusion caused by the unique blastoid terminology. Unfortunately, current character matrices (Bodenbender, 1995; Atwood, 2013) lack the explicit structure outlined by UEH and need to be reexamined to better capture character changes for phylogenetic analysis.

Blastoid systematics.-Traditionally, Blastoidea has been separated into two orders: Fissiculata and Spiraculata. These groupings are based on details of the external expression of the endothecal respiratory structures called hydrospires (Jaekel, 1918; Wanner, 1940; Fay, 1967). There are two common morphotypes of the external expression: fissiculates, which possess hydrospire slits, and spiraculates, which possess incurrent hydrospire pores at the edge of the ambulacra and excurrent spiracles, which are small, 
external openings at the end of completely internal hydrospire folds (Waters, 1988; Fig. 1).

These morphological groups have been examined separately on several occasions over the past 50 years (Breimer and Macurda, 1972; Macurda, 1983; Breimer, 1988a, b; Waters and Horowitz, 1993), but few studies have utilized rigorous phylogenetic methodologies to evaluate evolutionary relationships (Bodenbender, 1995; Bodenbender and Fisher, 2001). The results of a recent phylogenetic analysis by Atwood (2013) suggested that spiraculates are polyphyletic and nested within a larger fissiculate clade, agreeing with previous studies (Waters, 1990; Waters and Horowitz, 1993). In addition, several blastoids, such as Pentremoblastus and Conuloblastus, appear to be transitions between the fissiculate and spiraculate morphotypes. These genera have hydrospire slits that lead to bean-shaped or underdeveloped spiracles or have well-developed spiracles and hydrospire slits only partially covered by ambulacral side plates.

\section{Hydrospire morphology}

Respiratory structures of extinct blastozoan echinoderms are diverse, highly variable, and often clade defining (Paul, 1968, 1972; Sprinkle, 1973; Schmidtling and Marshall, 2010). The pores and associated structures of many blastozoans have been examined (Paul, 1968, 1972), but the explicit study of blastoid respiratory structures is lacking. Many studies (not limited to Breimer and Macurda, 1965; Macurda, 1967, 1969, 1975; Breimer and Joysey, 1968; Breimer et al., 1968; Breimer, 1970; Breimer and Dop, 1975; Macurda and Breimer, 1977) incorporated a thorough report of hydrospire structure into systematic descriptions, but few studies (Beaver, 1967; Dexter et al., 2009; Schmidtling and Marshall, 2010; Huynh et al., 2015) primarily discuss function or efficiency of these structures.

The respiratory structures of blastoids (i.e., hydrospires) were lightly calcified, porous, and fold-like internally (Beaver, 1967; Sprinkle, 1973). The two main morphotypes, fissiculate and spiraculate, are different both externally and internally. Fissiculates possess hydrospire slits, which are open to the exterior along the length of the hydrospire fold but are either covered by side plates or exposed above them and cross the deltoid-radial suture (Fig. 1.2). Spiraculates possess incurrent pores that line the ambulacra and are either positioned between the side plates or penetrate the adjacent radial and/or deltoid plate (Fig. 1.1).
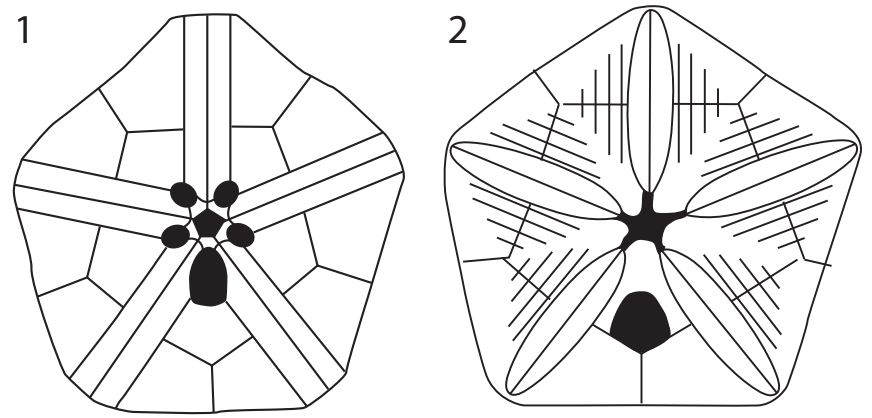

Figure 1. Generalized diagrams of the two primary blastoid morphotypes. (1) Spiraculate morphotype with incurrent hydrospire pores lining the ambulacra leading to four excurrent spiracles and one large anispiracle. (2) Fissiculate morphotype with four slits on each side of and parallel to the ambulacra crossing the radial-deltoid plate boundary. Modified from Beaver (1967).
The incurrent pores lead to hydrospire folds (ranging from one to 10 in number; Fig. 2) and finally to the excurrent openings, spiracles, at the summit (Sprinkle, 1973; Waters et al., 2017).

Hydrospire morphology and terminology can be confusing, specifically with the variation with fold number. Terminology herein follows the morphology outlined in Beaver (1967). In spiraculates, hydrospire folds occur at pores (Fig. 2.1-2.3) that are visible on the exterior of the organism. The pore leads to a hydrospire cleft, which is the portion of the fold between the pore and the final termination at the hydrospire tube (Fig. 2.1-2.3; hydrospire tube is synonymous with hydrospire canal in Schmidtling and Marshall, 2010). Some hydrospire clefts may bifurcate early (Fig. 2.2), whereas others are elongate and rest upon plates to accommodate additional folds (Fig. 2.3). At a given pore, multiple folds can be grouped to form hydrospire groups (Fig. 2.2, 2.3). The hydrospire tube is the expanded terminus of the fold that eventually leads to the spiracle opening at the top of the theca. Depending on the genus, this tube may reach the summit as a single spiracle or it may combine with adjacent tubes prior to reaching the summit.

Previous interpretations of these structures have either suggested that hydrospire walls were: (1) open meshworks that allowed for gaseous exchange between the coelomic fluids and ambient seawater (Macurda, 1973; Beaver, 1996) or (2) consisting of tiny calcite crystals (Beaver, 1967). Most workers assumed that the hydrospire walls were permeable, but the nature of wall preservation leaves little support for permeable folds (Beaver, 1996). The orientation of the section (perpendicular or oblique to the center axis of the blastoid) determines whether the more complex hydrospire meshwork is uncovered (Beaver, 1996). Macurda (1973) and Beaver (1996) provided evidence on the nature of the stereomic microstructure of blastoids as composed of a meshwork similar to that of modern echinoderms.

The external expression of hydrospires forms the basis of differentiation between fissiculates and spiraculates (Beaver et al., 1967); however, the internal architecture of hydrospires has yet to be studied. Typically, hydrospire data are drawn and reported from one to several sections near the top or center of the theca (e.g., Breimer et al., 1968; Breimer, 1970; Breimer and Dop, 1975; Macurda and Breimer, 1977). This can provide information on general size and number of folds but not on changes in shape and proportion as they pass through the thecal interior. It is, therefore, critical that in-depth examination of these structures be performed to provide a basis for understanding similarities and differences among taxa so that these data can be included into subsequent phylogenetic analyses. Hydrospires, unlike other internal structures (such as the gut and reproductive organs), are constructed of thin calcareous walls (Beaver, 1967) and are typically preserved within the theca. As the hydrospires are internal organs, new visualization methodology had to be developed (Waters et al., 2014, 2015) to digitally render and manipulate complete hydrospire structures. Preliminary work (Waters et al., 2014, 2015; Bauer et al., 2015) suggests that hydrospires occur in a variety of forms and are likely important in delineating higher taxonomic groupings.

\section{Materials and methods}

Paleozoic echinoderm workers have employed techniques such as producing thin sections or acetate peels to study internal 


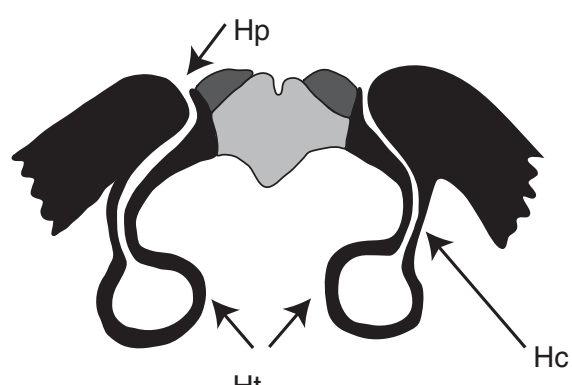

$\mathrm{Ht}$
2

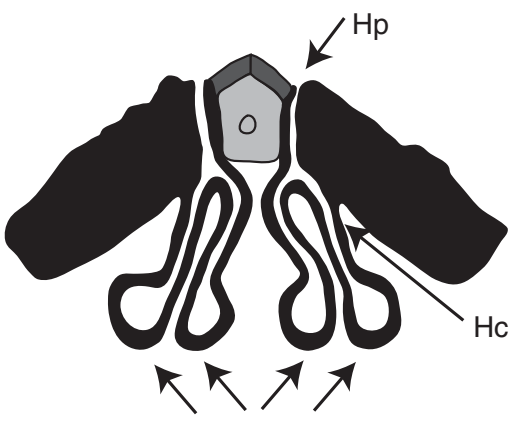

$\mathrm{Ht}$
3

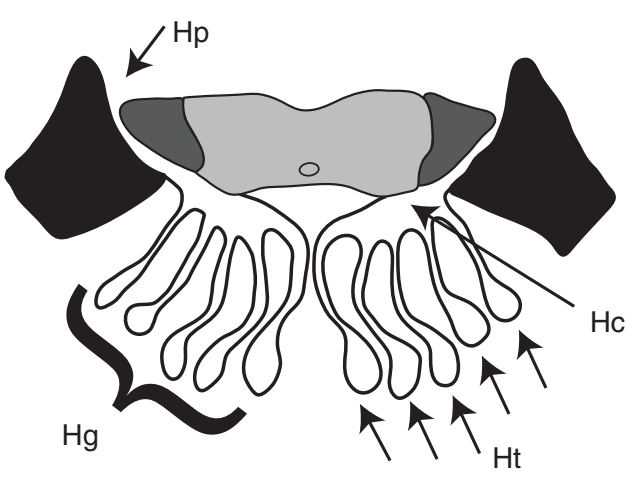

Lancet plate

Side plate

Radial plate

Figure 2. Ambulacral plating in relation to hydrospires in several representative spiraculate species. (1) Orbitremites derbiensis Sowerby, 1825 possessed a single hydrospire fold with a thin hydrospire cleft leading to the hydrospire tube at the end. (2) Globoblastus norwoodi (Owen and Shumard, 1850) possessed paired hydrospire folds with a bifurcating cleft leading to two hydrospire tubes. (3) Pentremites godoni (DeFrance, 1819) possessed five hydrospire folds within the hydrospire group; an elongate hydrospire cleft along the plates accommodates the additional folds. Hc = hydrospire cleft; Hg = hydrospire group; $\mathrm{Hp}=$ hydrospire pore; $\mathrm{Ht}=$ hydrospire tube. Modified from Beaver (1967).

morphology of organisms (e.g., Beaver et al., 1967; Beerbower, 1968; Breimer and Dop, 1975; Katz and Sprinkle, 1976, 1977; Broadhead, 1984; Breimer, 1988a, b; Waters and Horowitz, 1993; Dexter et al., 2009; Schmidtling and Marshall, 2010). Thin sections and acetate peels of serially sectioned thecae have previously been used to render hydrospire morphology in 2D (Breimer and Macurda, 1972) as well as 3D (Schmidtling and Marshall, 2010; Huynh et al., 2015). A comprehensive investigation of hydrospire morphotypes has recently begun in three dimensions (Waters et al., 2014, 2015; Bauer et al., 2015). For a more detailed discussion on methodology, see Waters et al. (2014, 2015). Herein, we describe the digital transformation of 2D serial peels into 3D models of hydrospire morphology for examination and character coding.

Acetate peel data.-A collection of unpublished serial acetate peels contains serial sections of 19 fissiculate species and 27 spiraculate species spanning the taxonomic diversity of Blastoidea. Peels were taken perpendicular to the thecal axis, and some of the peels contain minor flaws (e.g., wrinkles, tears, and bubbles), which can mask internal morphology or result in data loss (Waters et al., 2015). Peels were scanned (by J.A.W.) with a Braun slide scanner at 3,600 dpi and 8-bit grayscale. Once scanned, the peels were resized and compiled in Adobe Photoshop (Fig. 3.1) and the hydrospires were located and traced on each peel (Fig. 3.2). Once completed, the original photo layers were hidden, and what remained was a series of drawings that traced the hydrospires vertically through the theca. The image was then compressed and transferred into Rhinoceros, an industrial design program used to render 2D images in 3D. Within Rhinoceros, the images were connected to generate complete hydrospire structures (Fig. 3.3, 3.4).

Phylogenetic analysis.-As this work is ongoing, a phylogeny incorporating all known blastoid taxa is not currently available. Previously utilized external character data are undergoing largescale revision to provide a more complete data set to generate character suites that better characterize large morphological change (Supplemental Data 1). Herein, we investigate taxa that

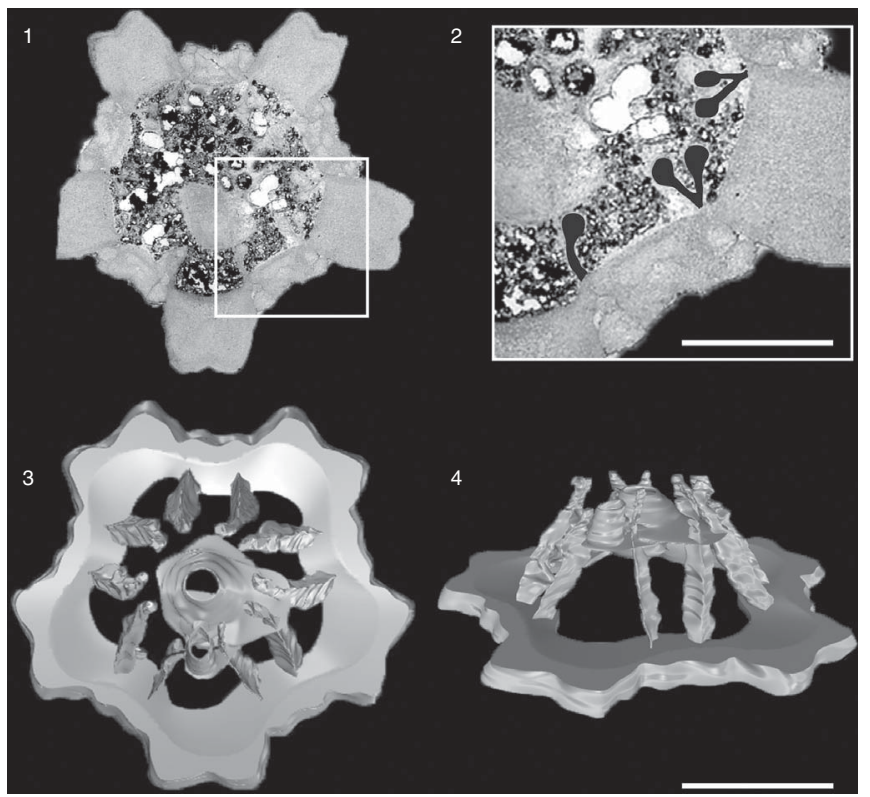

Figure 3. Deltoblastus permicus is an example of anatomical model reconstruction methodology. (1) Digital transverse slices are cut out and aligned in the same direction. Target areas of internal morphology can be identified as seen by the white box. (2) This enlarged box of (1) shows the hydrospires in the target area traced in black. Scale bar represents $0.5 \mathrm{~cm}$. (3) Aerial and (4) oblique lateral view of completed D. permicus model. (2) Scale bar $=0.5 \mathrm{~cm} ;(\mathbf{3}, 4)$ scale bar $=1 \mathrm{~cm}$. Modified from Waters et al. (2014) and Bauer et al. (2015).

have completed internal models in addition to several other taxa that have been suggested to be closely related (Atwood, 2013). The objective is to assess whether the addition of hydrospire data, although currently limited, has an effect on tree topology. Phylogenetic analysis was performed via maximum parsimony in PAUP* $4.0 \mathrm{~b} 10$ (Swofford, 2003). Characters were equally weighted and unordered and examined via exhaustive search parameters (Supplemental Data 2). The outgroup taxon was Stephanocrinus angulatus Conrad, 1842 based on sister taxon relationships identified in previous studies (Sprinkle, 1973; Broadhead, 1982, 1984; Brett et al., 1983). 
Repositories and institutional abbreviations.-Unpublished serial acetate peels reposited in the Naturalis Biodiversity Center in Leiden, Netherlands, were utilized for this study (Breimer and van Egmond, 1968). Raw scanned peel data are available in Supplemental Data 3-8.

\section{Results and discussion}

Hydrospire morphology.-There have been six models generated thus far: Monoschizoblastus rofei (Etheridge and Carpenter, 1882) (Fig. 4.13-4.15), Ellipticoblastus ellipticus (Sowerby, 1825) (Fig. 4.10-4.12), Diploblastus glaber (Meek and Worthen, 1869) (Fig. 4.7-4.9), Deltoblastus permicus (Wanner, 1910) (Fig. 4.4-4.6), Cryptoblastus melo (Owen and Shumard, 1850) (Fig. 4.16-4.18), and Pentremites godoni (DeFrance, 1819) (Fig. 4.1-4.3). All of these taxa have spiraculate morphologies and represent the late Paleozoic spiraculate gross body plan. Examination and description of hydrospire structure from the completed models show them to be character-rich and allow the identification of several novel characters. The number of hydrospire folds has previously been used to delineate taxa, and by including this character in the analysis, it will be possible to test the validity of using hydrospire count to erect taxa.

The number of hydrospire folds in each group (i.e., the series of folds that form a single respiratory structure) varies between the models. The numerous species of Pentremites vary in the number of hydrospires per group, and this number can vary between individuals of the same species and ontogenetically (Macurda, 1967; Macurda and Breimer, 1977; Dexter et al., 2009), although this is exceptional. In most taxa with one or two folds, the number is consistent among individuals. However, some taxa have fewer hydrospire folds on the anal side, likely providing additional space for associated structures such as the gonads and/or anus. This can be seen in two of the six models (Fig. 4.1-4.6). In D. permicus, for example, hydrospire folds are paired in each group except for those within the CD interray (the anal side), where single folds are present (Fig. 4.4-4.6). This reduction is also seen in $P$. godoni, where the anal side has four folds per group, whereas other groups all contain five folds (Fig. 4.1-4.3). This reduction is not seen in either E. ellipticus or $M$. rofei, and these taxa have a single fold per group whereas $D$. glaber and $C$. melo have two folds per group.

Variation of hydrospire morphology suggests their utility to differentiate taxa. Two of the six completed models, E. ellipticus and $M$. rofei, are within the traditionally described family, Orbitremitidae, but show variable hydrospire morphology (Fig. 4.10-4.15). Ellipticoblastus ellipticus (Fig. 4.10-4.12) has hydrospire fold pairs that begin nearly the same distance apart as those of M. rofei (Fig. 4.13-4.15) but remain closer together as they extend vertically toward the spiracles. The paired hydrospire folds of $M$. rofei bow outward slightly prior to tapering nearer to the spiracle openings (Fig. 4.13). The number of hydrospire folds in each group also varies between families. Diploblastus glaber (Fig. 4.7-4.8) and D. permicus (Fig. 4.4-4.5) show two folds within each group, whereas both E. ellipticus and $M$. rofei have a single fold per group.

In addition, the surface area of the fold is variable between the generated models. Deltoblastus permicus (Fig. 4.4-4.6), M. rofei (Fig. 4.13-4.15), and C. melo (Fig. 4.16-4.18) all have folds that extend shallowly into the coelomic cavity compared to E. ellipticus (Fig. 4.10-4.12) and D. glaber (Fig. 4.7-4.9), both of which extend further into the coelomic cavity. Rather than increasing the extent of the folds, P. godoni (Fig. 4.1-4.3) has additional narrow folds to increase the surface area. The variation in surface area is likely directly related to gaseous exchange between the hydrospires and the coelomic cavity (Dexter et al., 2009). The hydrospire cleft (Fig. 2) is also variable among these species and may be related to changing the surface area of the fold. Monoschizoblastus rofei possesses a long, thin cleft (Fig. 4.14), whereas D. glaber has a short, stout cleft (Fig. 4.9). Pentremites godoni has an elongate cleft to accommodate the additional folds present at each pore.

Notable variation exists for the ratio of hydrospire pores to hydrospire folds to spiracular openings. In $M$. rofei, there is a single fold per pore, and each of these folds extends through the theca and is expressed as an individual spiracle at the summit (Fig. 4.13, 4.14). Conversely, in P. godoni, there are five folds per pore that merge into a single tube that extends toward the summit. Finally, this tube merges with an adjacent tube to be expressed as a spiracle at the summit (Fig. 4.14).

Although only six models were generated for this study, all of the spiraculate morphotype, it is clear there is significant variation both between and within previously described families. Additional models of all morphotypes will result in an increased understanding of variation and similarities between hydrospire structures.

Blastoid phylogeny.-The morphology described in the preceding provides a baseline to evaluate internal character data for blastoids. Preferably, all of the taxa used to infer blastoid phylogeny would be represented by species for which there are both specimens to code external morphology and peel data to code internal morphology. As there were only a few taxa (nine) in this analysis, character data had to be reduced to examine the relationships between these taxa. This was done by examining all character data as a whole and determining characters that were constant and uninformative among the taxa. The uninformative

\footnotetext{
Figure 4. (1, 2) Anatomical model of respiratory structures of Pentremites godoni (DeFrance, 1819) in (1) oblique lateral and (2) aerial views. (3) Representative section of $P$. godoni showing the abundance of folds, elongate cleft, and plate boundaries. (4, 5) Anatomical model of respiratory structures of Deltoblastus permicus (Wanner, 1911) in (4) oblique lateral and (5) aerial views; note the reduction of hydrospire folds in the anal area. (6) Representative section of D. permicus showing the petite hydrospires and thick plates. $(\mathbf{7}, \mathbf{8})$ Anatomical model of respiratory structures of Diploblastus glaber (Meek and Worthen, 1869) in (7) oblique lateral and (8) aerial views. (9) Representative section of D. glaber showing paired folds in each group and a stout hydrospire cleft. (10, 11) Anatomical model of respiratory structures of Ellitpicoblastus ellipticus (Sowerby, 1825) in (10) oblique lateral and (11) aerial views. (12) Representative section of E. ellipticus showing the long thin hydrospire cleft of each hydrospire fold. (13, 14) Anatomical model of respiratory structures of Monoschizoblastus rofei (Etheridge and Carpenter, 1882) in (13) oblique lateral and (14) aerial views. (15) Representative section of $M$. rofei exhibiting single folds per group. (16, 17) Anatomical model of Cryptoblastus melo (Owen and Shumard, 1850) in (16) oblique lateral and (17) aerial views. (18) Representative section of $C$. melo exhibiting short bifurcating hydrospire clefts, circular hydrospire ducts, and clear plate boundaries. All scale bars $=5$ mm.
} 


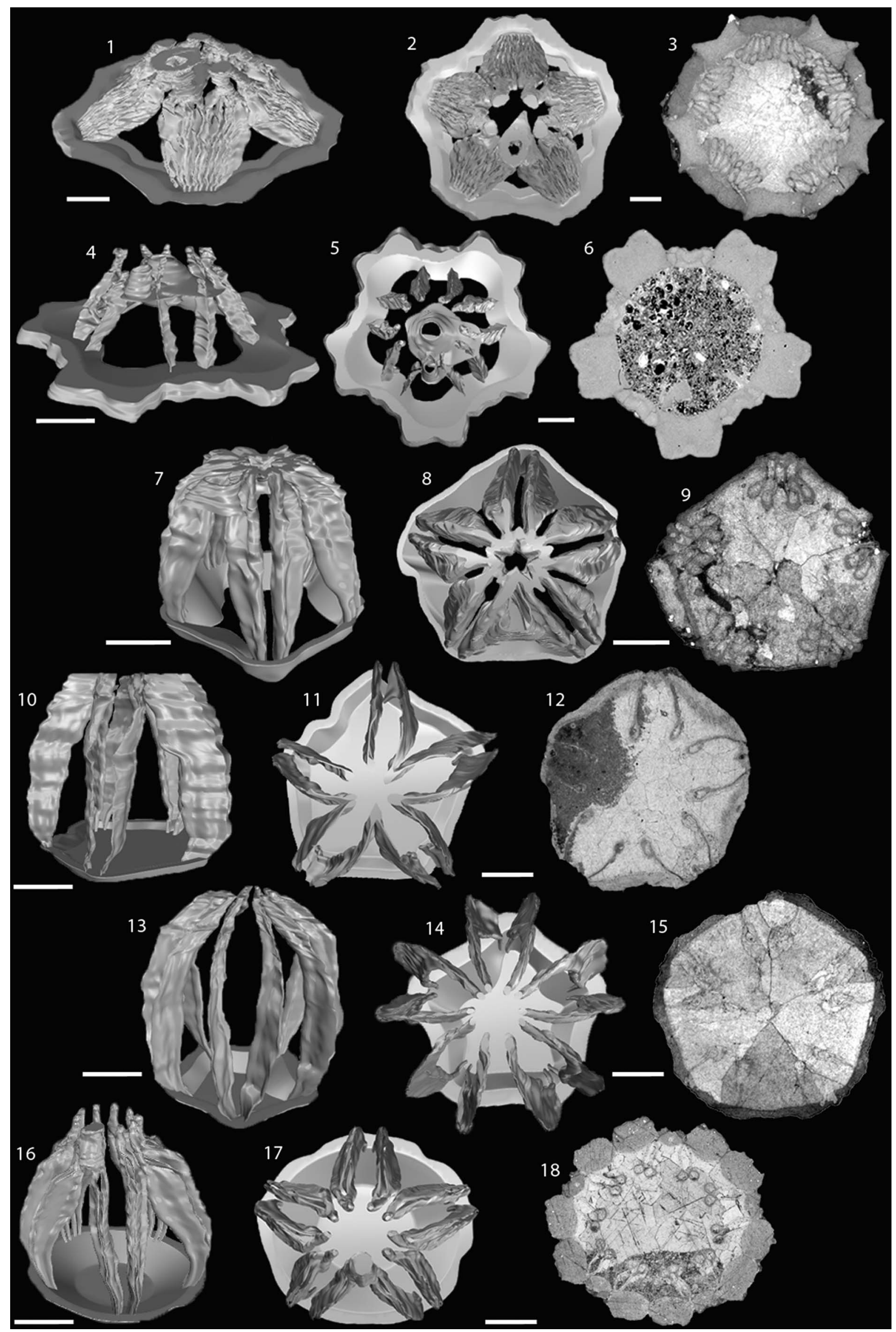


1

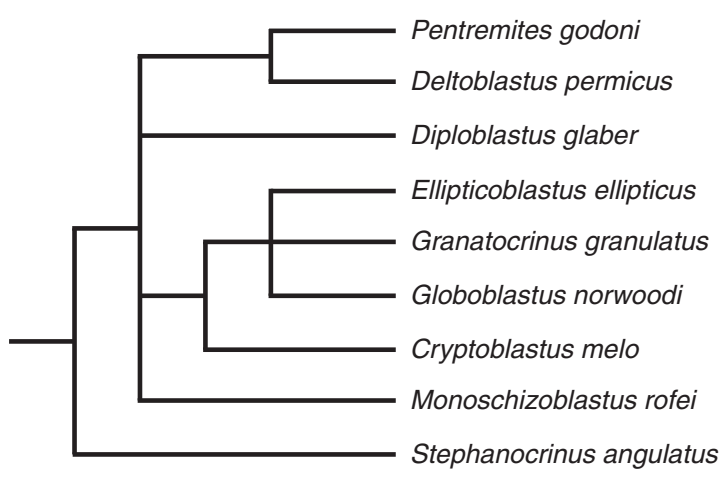

2

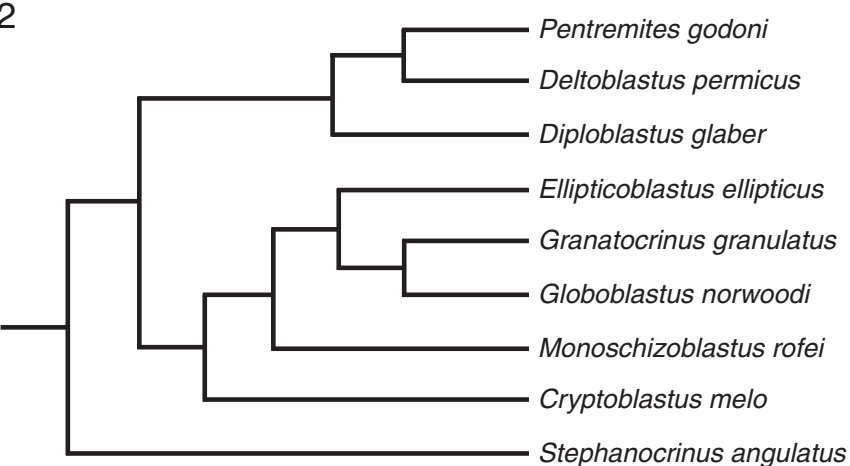

Figure 5. (1) Strict consensus tree of seven most parsimonious trees with tree lengths of 52 without the addition of hydrospire data (CI 0.645, RI 0.486, RC 0.309). (2) Strict consensus tree of one most parsimonious tree with the addition of hydrospire data with a length of 60 (CI 0.650 , RI 0.488 , RC 0.317).

characters were removed and the analysis was performed again without hydrospire data in the matrix (Fig. 5.1). An additional analysis was then performed on this matrix with the hydrospire data included (Fig. 5.2).

The tree topology without the hydrospire data (Fig. 5.1) is largely unresolved with a polytomy at the base in the strict consensus of the nine equally most parsimonious trees, with several small groupings of taxa but relatively little resolution. Pentremites godoni and D. permicus form a sister pair, but their relationship to other taxa is unresolved. Ellipticoblastus ellipticus, G. granulatus (Roemer, 1851), and G. norwoodi (Owen and Shumard, 1850) form a smaller polytomy with a sister taxon of $C$. melo. Both D. glaber and $M$. rofei are in an unresolved relationship with these two groupings of taxa.

The addition of hydrospire data does not significantly alter tree topology (Fig. 5.2) but does provide resolution within the smaller groupings of taxa. The pairing of $P$. godoni and $D$. permicus is now sister group to $D$. glaber, united by the number of respiratory fields. The pairing of $P$. godoni and $D$. permicus is further supported by the shared reduction of hydrospire folds in the anal area. The grouping of E. ellipticus, G. norwoodi, G. granulatus, and M. rofei is supported by the ambulacra being in line with surrounding thecal plates, the number of respiratory folds per field, and the transitions from hydrospire fold to spiracle. The wide hydrospire folds of E. ellipticus support its separation from the pairing of G. norwoodi and G. granulatus. The clade of G. granulatus, G. norwoodi, M. rofei, and E. ellipticus is sister group to M. rofei in the analysis containing hydrospire data rather than $C$. melo in the data set lacking hydrospire data. This shows that the addition of hydrospire data can support novel relationships that are not supported by external data alone.

This preliminary analysis provides support that the incorporation of internal character data aids in understanding evolutionary relationships among blastoid taxa. Although only five additional internal characters were added to the amended character matrix of 29 characters, these characters appear to provide additional resolution both within and between groupings of blastoids and, in one case, novel relationships.

\section{Future directions}

Respiratory structures of blastozoan echinoderms have been long considered synapomorphies for clades and often are used to delineate species (Sprinkle, 1973). While internal character data have previously been successfully incorporated into phylogenetic inference for fossil taxa (Leighton and Maples, 2002; Wright and Stigall, 2013, 2014; Bauer and Stigall, 2016), this study is the first to do so with Blastoidea. Although the internal anatomical models used in this study are currently limited, we provided evidence that respiratory structures provide further resolution to a phylogenetic hypothesis because they bring more data to bear in the inferred phylogeny. With more complete taxonomic coverage of blastoid hydrospire structure, the inferred blastoid phylogeny will provide a basis to support or reject the groupings of Fissiculata and Spiraculata, a framework for taxonomic revision, and a basis for testing evolutionary questions throughout the Paleozoic.

In addition to the hydrospires being identifiable in serial sections, thecal plate boundaries can be clearly outlined in the peels (Fig. 4.3, 4.6, 4.9, 4.12, 4.15, 4.18). Plates of particular interest for internal anatomy include the lancet, which can occur exposed or concealed along the length of the ambulacra by the side plates. The lancet and adjacent side plates are important as the hydrospire pores are often found along the plate sutures. Questions concerning plate origination and persistence throughout the theca can be examined. Incorporation of all morphological details will provide a fuller understanding of early echinoderm relationships. Data derived from the evolutionary history of the blastoids can therefore be applied to other echinoderm groups to aid in inferring the relationships among members of this diverse clade.

\section{Systematic paleontology}

Remarks.-Descriptions are based on the modeled hydrospire structures and acetate peel images. As the data set was a legacy collection, the descriptions are based on the peels available for study. The extent of the peels through the specimens was at the discretion of those that generated the peels (A. Breimer), resulting in several models being incomplete (noted in the following). Although it is a variation on normal systematic descriptions, the authors feel that a thorough examination and description of the structures is necessary and provides the framework for understanding subtle similarities and differences between species. The objective, therefore, is to provide descriptions relating the internal anatomy to the external expression of the respiratory structures. These models are 
currently being utilized to simulate functional morphology of blastoids (e.g., Waters et al., 2017) but are available on request by contacting the corresponding author.

Class Blastoidea Say, 1825

Family Granatocrinidae Fay, 1961a

Genus Cryptoblastus Etheridge and Carpenter, 1886 Cryptoblastus melo (Owen and Shumard, 1850)

Figure 4.16-4.18

1850 Pentremites melo Owen and Shumard, p. 65, pl. 7, fig. $14 \mathrm{a}-\mathrm{c}$.

1886 Cryptoblastus melo; Etheridge and Carpenter, p. 232, pl. 7, figs. 14, 15 .

1894 Cryptoblastus melo; Keyes, p. 139, pl. 18, fig. 7a, b.

1903 Cryptoblastus melo; Hambach, p. 40.

1937 Cryptoblastus melo; Cline, p. 636.

1944 Cryptoblastus melo; Cline, p. 137, pl. 51, figs. 32-34.

1961a Cryptoblastus melo; Fay, p. 61, pl. 38, figs. 6-9; textfigs. 98-100.

1962 Cryptoblastus melo; Armstrong, p. 65, pl. 9, figs. 31-40. 1969 Cryptoblastus cf. melo; Macurda, p. 463, pl. 63, figs.14, 15.

For a complete pre-1937 bibliography of the species synonymies, the reader is referred to Cline (1937, p. 636).

Description.-Two folds in each group; fold pairs remain close together from base to summit; hydrospire cleft begins small at base, becomes longer toward wider portion of theca, then tapers again as it reaches spiracles, making widest portion of each fold closer to spiracle opening. Overall folds are rather narrow; fold pairs of adjacent groups (same lancet plate) begin close together and bow out slightly, increasing toward top where fold pair becomes closer with fold pair from the adjacent lancet plate. Each group of fold pairs merges to form single spiracle. Anal area reduction absent in $C$. melo, but anal area folds are merged with anus forming anispiracle, ending with eight small openings and one large opening on the summit.

Remarks.-Cryptoblastus melo is placed within the family Granatocrinidae; no other models currently exist within this group. Similarities can be drawn from C. melo, E. ellipticus, and M. rofei in that the hydrospire canal migrates toward the central axis of the theca. The merged canal of fold pairs appears to extend for a distance that is elongate compared to the other models, with the only other 'elongate' canal being present in $P$. godoni. Unfortunately, it is difficult to assess whether this is truly a unique feature or whether there are summit data missing from other models. The anatomical reconstruction is consistent with previous studies and information on the internal data of C. melo.

\section{Family Schizoblastidae Fay, 1961a \\ Genus Deltoblastus Fay, 1961b \\ Deltoblastus permicus (Wanner, 1910)}

Figure 4.4-4.6

1910 Schizoblastus permicus Wanner, p. 138, pl. 2, figs. 8, 9. 1924 Schizoblastus permicus Wanner, p. 69, pl. 6, figs. 13-18; pl. 7, figs. 9-12; pl. 8, figs. 1-3.
1924 Schizoblastus permicus ellipticus; Wanner, p. 74, pl. 3, figs. 16-19; pl. 4, figs. 1-8.

1924 Schizoblastus magnificus; Wanner, p. 62, pl. 5, figs. 12-13.

1932 Schizoblastus permicus ellipticus; Wanner, pl. 1, figs. 1-6, 8, 9, 11-13; pl. 2, figs. 14-23, 39; pl. 3, figs. 26-33; pl. 4, figs. $34,37,46$.

1932 Schizoblastus permicus Wanner, pl. 2, fig. 24a, b.

1934 Schizoblastus permicus Jansen, p. 823, text-fig. 5.

1961b Deltoblastus ellipticus; Fay, p. 37.

1961b Deltoblastus magnificus; Fay, p. 38.

1961b Deltoblastus permicus; Fay, p. 38, pl. 1, figs. 1-18.

Description.-Two folds in each group; hydrospire cleft remains relatively stable in length for duration of folds, each fold pair reaching surface as single spiracle. Overall folds rather narrow but uniform; folds do not extend far into coelomic cavity but extend short distance from interior plate walls; groups of adjacent fold pairs (same lancet plate) positioned closely together and angle out very slightly, increasing toward top, where fold pair approaches fold pair from adjacent lancet plate. Anal area reduction present in D. permicus but anal area spiracles small and separate from anus, ending with eleven openings on summit.

Remarks.-Deltoblastus permicus is placed within the family Schizoblastidae; no other models currently exist for this group. The model for $D$. permicus is incomplete, stopping at or near the deltoid-radial suture. Either the sectioning process was terminated due to ample data from the already sectioned portion of the theca or the structures did not continue or were not visible in the next portion of the theca. The lack of additional sections prevents an understanding of hydrospire duration in the theca. This model is one of two with a reduction in hydrospire folds in the anal area. In addition, the hydrospire canal in this model does not extend far into the body cavity as all of the other models do; this results in narrow folds with decreased surface area. The anatomical reconstruction is consistent with previous studies and information on the internal data of D. permicus.
Family Troosticrinidae Bather, 1899
Genus Diploblastus Fay, 1961a
Diploblastus glaber (Meek and Worthen, 1869)

Figure 4.7-4.9

1869 Granatocrinus glaber Meek and Worthen, p. 91.

1873 Granatocrinus glaber Meek and Worthen, p. 537, pl. 20, fig. 11.

1903 Granatocrinus glaber Hambach, p. 65.

1961a Diploblastus glaber; Fay, pl. 48, figs. 1-12; pl. 49, figs. 1-9; text-figs. 113-119.

Description.-Two folds in each group; hydrospire cleft short and stout with apparent increase in length around center of specimen, tapering toward summit; stout cleft provides apparent robustness to hydrospire structure; this robustness clouds ability to clearly identify each fold in completed model; each fold increases in width from bottom, which starts as narrow and increases in extent into the coelomic cavity as it approaches 
summit, maximum width attained prior to reaching summit, where subsequent narrowing of fold occurs; each fold pair reaching surface $\mathrm{V}$-shaped spiracle around associated deltoid plate. Overall folds are wide; adjacent groups (same lancet plate) begin close together and retain same distance for duration of structures, increasing toward top, where fold pair approaches fold pair from adjacent lancet plate. Anal area reduction absent in D. glaber, but anal area spiracles confluent with anus forming anispiracle, ending with four paired spiracles and an anispiracle on summit.

Remarks.-Diploblastus glaber is placed within the family Troosticrinidae; no other models currently exist for this group. This species has a single pore leading to two folds that persist to the top and join to form a V-shaped spiracle, seen in the model. The hydrospire canal migrates into the body cavity, similar to the other models, from the base to the summit and produces a relatively wide fold. Although not entirely clear in the model (visible in the peels; Fig. 4.9), the hydrospire cleft is incredibly robust, a feature unique to this model. The anatomical reconstruction is consistent with previously described internal data by Breimer (1988b), where several sections were used to discuss internal morphology and plate arrangements.

\section{Family Orbitremitidae Bather, 1899 \\ Genus Ellipticoblastus Fay, 1960 \\ Ellipticoblastus ellipticus (Sowerby, 1825)}

Figure 4.10-4.12

1825 Pentremites elliptica Sowerby, p. 317, pl. 11, fig. 4.

1863 Elaeacrinus ellipticus; Shumard, p. 112.

1959 Orbitremites ellipticus; Joysey, p. 99, pl. 2, figs. 1-9.

1961a Orbitremites ellipticus; Fay, p. 89, pl. 43, figs. 1-3, 10, 11, text-figs. 186, 187.

1968 Ellipticoblastus ellipticus; Breimer and Joysey, p. 181, text-figs. 1, 2.

Description.-One fold in each group; hydrospire cleft thin and long with apparent increase in length around center of specimen, with top half of structure having longer cleft length than base; each fold combining with adjacent fold to produce five spiracles. Folds wide and occupy significant portion of the coelomic cavity; adjacent groups (same lancet plate) begin close together and bow out slightly, tapering again toward summit where fold pair approaches fold pair from adjacent lancet plate because of increased cleft length allowing folds to meet in center; this produces external expression of single spiracle openings. Anal area reduction absent in E. ellipticus; anal area spiracles are confluent with anus, ending with five openings on summit.

Remarks._Ellipticoblastus ellipticus is placed within the family Orbitremitidae; one other model (M. rofei) currently exists for this group. The hydrospire canal migrates far into the body cavity producing thin but wide folds unlike the other models. The fold pairs in E. ellipticus remain relatively equidistant from one another throughout the theca whereas those of $M$. rofei bow outward in the center of the theca. The anatomical reconstruction is consistent with previously described (Breimer and Joysey, 1968) internal data of E. ellipticus.
Genus Monoschizoblastus Cline, 1936 Monoschizoblastus rofei (Etheridge and Carpenter, 1882) Figure 4.13-4.15

1882 Granatocrinus rofei Etheridge and Carpenter, p. 239.

1886 Schizoblastus rofei; Etheridge and Carpenter, p. 228 , pl. 6, fig. 17; pl. 8, figs. 9-11; pl. 17, fig. 2.

1886 Schizoblastus bailyi; Etheridge and Carpenter, p. 223, pl. 16, figs. 12, 13.

1936 Monoschizoblastus bailyi; Cline, p. 265.

1936 Monoschizoblastus rofei; Cline, p. 265.

Description.- One fold in each group; hydrospire cleft thin and does not extend far into coelomic cavity; tapering toward summit becoming narrow again; each fold reaching surface as spiracle with exception of those in anal area. Overall folds are narrow; adjacent groups (same lancet plate) begin close together and bow outward three times distance at origination, tapering toward summit where each fold subsequently approaches fold at adjacent lancet plate. Anal area reduction absent in $M$. rofei; anal area spiracles are confluent with anus, ending with nine openings on summit.

Remarks.-Monoschizoblastus rofei is placed within the family Orbitremitidae; one other model (E. ellipticus) currently exists for this group. Similar to E. ellipticus, M. rofei had a single pore leading to a single fold, but unlike E. ellipticus, each fold (except those in the anal area) terminates as a spiracle. As with the majority of the models, the hydrospire canal migrates toward the center axis of the body cavity but does not extend as far in as the folds of E. ellipticus. The anatomical reconstruction is consistent with previous studies and information on the internal data of M. rofei.

\section{Family Pentremitidae d'Orbigny, 1852 Genus Pentremites Say, 1820 \\ Pentremites godoni (DeFrance, 1819)}

Figure 4.1-4.3

1819 Encrina godonii DeFrance, p. 467.

1821 Encrinites florealis; von Schlotheim, p. 339.

1825 Pentremites florealis; Say, p. 295.

1826 Pentremites florealis; Goldfuss, p. 150, pl. 50, fig. 2a-c.

1851 Pentremites florealis; Roemer, p. 353, pl. 4, figs. 1-4; pl. 5, fig. 8.

1858 Pentremites godoni; Hall, p. 692, pl. 25, fig. 13.

1881 Pentremites godoni; White, p. 511, pl. 7, figs. 10, 11.

1886 Pentremites godoni; Etheridge and Carpenter, p. 157, pl. 1 , fig. 11 ; pl. 2, figs. $1-13$; pl. 12, figs. 16, 17; pl. 16, figs. 19, 22, 23.

1898 Pentremites godoni; Weller, p. 414.

1920 Pentremites godoni; Weller, p. 319, pl. 4, figs. 31-34, 36.

1917 Pentremites godoni; Ulrich, p. 254, pl. 5, fig. 26.

1917 Pentremites planus; Ulrich, pl. 5, figs. 1-13.

1957 Pentremites godoni; Galloway and Kaska, p. 48, pl. 3, figs. 11-13; pl. 11, figs. 20-30; pl. 13, figs. 9-12.

1961a Pentremites godoni; Fay, p. 90, text-fig. 188.

1961c Pentremites godoni; Fay, p. 871, text-fig. 1, figs. 1-4. 
Description.-Five folds in each group; fold groups tightly packed making it difficult to distinguish folds in model; original peels provide a clear distinction of each fold; hydrospire cleft thin and elongate to accommodate each of five folds with apparent increased length around center of the specimen, tapering toward summit; each fold group (five folds) merges into single canal, then adjacent canals (separate lancet plates) merge to form single large spiracle opening. Folds narrow but numerous; fold groups at same lancet plate begin close together and angle out slightly, increasing toward top, where fold group approaches fold group from adjacent lancet plate. Anal area reduction present in $P$. godoni and anal area spiracles confluent with anus forming anispiracle, ending with five openings on summit.

Remarks.-Pentremites godoni is placed within the family Pentremitidae; no other models currently exist for this group. The model for $P$. godoni is incomplete, missing the lower portion of the theca; the spiracle and anal openings are clear in the model. The sectioning process was likely terminated because the portion that had already been sectioned was enough to address what was being investigated. It should also be noted that although this is an individual within the species $P$. godoni, it has been noted that fold number is variable within a species. The extent of the hydrospires through the theca is not clear as a large portion of the specimen is missing from this reconstruction.

As with the other models, it appears that the hydrospire canal is migrating toward the center axis. Unfortunately, since this is only the top of the specimen, it is not clear whether the remainder of the structure would follow a similar pattern to the other models. Each hydrospire pore leads to four (in the anal area) or five folds, which form a single canal near the summit and finally combine with an adjacent fold group to produce a single spiracle. The folds of $P$. godoni are narrow but numerous, unlike any of the other models.

\section{Acknowledgments}

We thank J. Sprinkle, T. Dexter, I. Rahman, J. Jin, and an anonymous reviewer for constructive comments that helped us improve this manuscript. L. White generated the models discussed in this paper, and both she and B. Nguyen taught the authors to properly visualize the structures in three dimensions. We also acknowledge ROA grants to Appalachian State University from NSF DEB 1036260 and the Appalachian State University Foundation, which supported this project and the aforementioned students. Naturalis Biodiversity Center in Leiden, Netherlands, provided access to specimens housed in their institutions. This study was supported by The University of Tennessee Discretionary Funds (J.E.B.). This paper is a contribution to Progress in Echinoderm Paleobiology.

\section{Accessibility of supplemental data}

Supplemental data available from the Dryad Digital Repository: doi:10.5061/dryad.1d1m6.

\section{References}

Armstrong, R.L., 1962, Stratigraphy and paleontology of the Mississippian System in southwestern New Mexico and adjacent southeastern Arizona: State Bureau of Mines and Mineral Resources, New Mexico Institute of Mining and Technology, Memoir 8, $99 \mathrm{p}$.

Atwood, J.W., 2013, Species discrimination, systematics, and ontogeny of Blastoidea [Ph.D. dissertation]: Knoxville, The University of Tennessee, $172 \mathrm{p}$.

Atwood, J.W., and Sumrall, C.D., 2012, Morphometric investigation of the Pentremites fauna from the Glen Dean Formation, Kentucky: Journal of Paleontology, v. 86, p. 813-828.

Bather, F.A., 1899, The genera and species of Blastoidea, with a list of the specimens in the British Museum (Natural History): London, Taylor Francis Printers, $70 \mathrm{p}$.

Bauer, J.E., and Stigall, A.L., 2016, A combined morphometric and phylogenetic revision of the Late Ordovician brachiopod genera Eochonetes and Thaerodonta: Journal of Paleontology, v. 90, 888-909.

Bauer, J.E., Sumrall, C.D., and Waters, J.A., 2015, Classifying blastoids through hydrospire morphology, in Zamora, S., and Rábano, I., eds., Progress in Echinoderm Palaeobiology: Cuadernos del Museo Geominero, 19. Instituto Geológico y Minero de España, Madrid, p. 33-36.

Beaver, H.H., 1967, Morphology, hydrospires, in Moore, R.C., ed., Treatise on Invertebrate Paleontology, Pt. S, Echinodermata 1, v. 2: New York and Lawrence, Geological Society of America and University of Kansas, p. S300-S344.

Beaver, H.H., 1996, Hydrospire meshwork of the Carboniferous blastoid Pentremites Say: Journal of Paleontology, v. 70, p. 333-335.

Beaver, H.H., Fay, R.O., Macurda, D.B., Jr., Moore, R.C., Ubaghs, G., and Wanner, J., 1967, Blastoids, in Moore, R.C., ed., Treatise on Invertebrate Paleontology, Pt. S, Echinodermata 1, v. 2: New York and Lawrence, Geological Society of America and University of Kansas, p. S297-S455.

Beerbower, J.R., 1968, Search for the Past, Upper Saddle River, New Jersey, Prentice-Hall, p. 512.

Bodenbender, B., 1995, Morphological, crystallographic, and stratigraphic data in cladistics analyses of blastoid phylogeny: University of Michigan Museum of Paleontology Contributions, v. 29, p. 201-257.

Bodenbender, B.E., and Fisher, D.C., 2001, Stratocladistic analysis of blastoid phylogeny: Journal of Paleontology, v. 75, p. 351-369.

Breimer, A., 1970, Two new species of Spanish Devonian blastoids: Proceedings of the Koninklijke Nederlandse Akademie van Wetenschappen, Series B, v. 73, p. $97-108$.

Breimer, A., 1988a, The anatomy of the spiraculate blastoids; Part I: The family Troosticrinidae: Proceedings of the Koninklijke Nederlandse Akademie van Wetenschappen, Series B, v. 91, p. 1-13.

Breimer, A., 1988b, The anatomy of the spiraculate blastoids; Part II: The family Diploblastidae: Proceedings of the Koninklijke Nederlandse Akademie van Wetenschappen, Series B, v. 91, p. 161-169.

Breimer, A., and Dop, A.J., 1975, An anatomic and taxonomic study of some Lower and Middle Devonian blastoids from Europe and North America: Proceedings of the Koninklijke Nederlandse Akademie van Wetenschappen, Series B, v. 78, p. 39-61.

Breimer, A., and Joysey, K.A., 1968, Anatomical studies of Orbitremites and Ellipticoblastus (Blastoidea) I: Proceedings of the Koninklijke Nederlandse Akademie van Wetenschappen, Series B, v. 71, p. 124-136.

Breimer, A., and Macurda, D.B., Jr., 1965, On the systematic position of some blastoid genera from the Permian of Timor: Proceedings of the Koninklijke Nederlandse Akademie van Wetenschappen, Series B, v. 68, p. 209-217.

Breimer, A., and Macurda, D.B., Jr., 1972, The Phylogeny of Fissiculate Blastoids: Verhangelingen der Koninklijke Nederlandsche Akademie van Wetenschappen, Afdeling Natuurkunde, Eerste Reeks, Deel 26, 390 p.

Breimer, A., and van Egmond, H.A., 1968, A new development of the acetate peel technique for use on fossil echinoderms. Proceedings of the Koninklijke Nederlandse Akademie van Wetenschappen Series B, v. 71, p. 144-149.

Breimer, A., Macurda, D.B., Jr., and Prokop, R.J., 1968, New Lower Devonian blastoids from Bohemia: Proceedings of the Koninklijke Nederlandse Akademie van Wetenschappen, Series B, v. 71, p. 191-202.

Brett, C.E., Frest, T.J., Sprinkle, J., and Clement, C.R., 1983, Coronoidea: A new class of blastozoan echinoderms based on taxonomic reevaluation of Stephanocrinus: Journal of Paleontology, v. 57, p. 627-651.

Broadhead, T.W., 1982, Reappraisal of Class Eocrinoidea (Echinodermata), in Lawrence, J.M., ed., Echinoderms: Proceedings of the International Conference, Tampa Bay: A.A. Balkema, Rotterdam, p. 125-131.

Broadhead, T.W., 1984, Macurdablastus, a Middle Ordovician blastoid from the Southern Appalachians: University of Kansas Paleontological Contributions, Paper 110, p. 1-9.

Cline, L.M., 1936, Blastoids of the Osage group, Mississippian: part I. The genus Schizoblastus: Journal of Paleontology, v. 10, p. 260-281. 
Cline, L.M., 1937, Blastoids of the Osage group, Mississippian: part II. The genus Cryptoblastus: Journal of Paleontology, v. 11, p. 634-649.

Cline, L.M., 1944, Class Blastoidea, in Shimer, H.W., and Shrock, R.R., eds., Index Fossils of North America, New York, Wiley \& Sons, p. 133-137.

Conrad, T.A., 1842, Observations of the Silurian and Devonian systems of the United States with descriptions of new organic remains: Journal of the Academy of Natural Sciences in Philadelphia, v. 8, p. 183-190.

DeFrance, M.J.L, 1819, Encrines: Dictionnaire des Sciences Naturales, v. 14 EA-EOU, p. 461-468.

Dexter, T.A., Sumrall, C.D., and McKinney, M.L., 2009, Allometric strategies for increasing respiratory surface area in the Mississippian blastoid Pentremites: Lethaia, v. 42, p. 127-137.

d'Orbigny, A.D., 1852, Cours elémentaire de paleontology et de géologie stratigraphiques: Paris, Mason, $841 \mathrm{p}$.

Etheridge, R., and Carpenter, P.H., 1882, On certain points in the morphology of the Blastoidea, with descriptions of some new genera and species: Annals and Magazine of Natural History, ser. 5, v. 9, p. 213-252.

Etheridge, R., and Carpenter, P.H., 1886, Catalogue of the Blastoidea in the Geological Department of the British Museum (Natural History), with an account of the morphology and systematic position of the group, and a revision of genera and species: London, British Museum Catalogue, $332 \mathrm{p}$.

Fay, R.O., 1960, The type species of Obritremites Austin and Austin 1842, and Ellipticoblastus, a new Mississippian genus: Oklahoma Geology Notes, Oklahoma Geological Survey, v. 20, p. 315-317.

Fay, R.O., 1961a, Blastoid studies: University of Kansas Paleontological Contributions, Article 3, $147 \mathrm{p}$

Fay, R.O., 1961b, Deltoblastus, a new Permian blastoid from Timor: Oklahoma Geology Notes, v. 21, p. 36-40.

Fay, R.O., 1961c, The type of Pentremites Say: Journal of Paleontology, v. 35, p. $868-873$

Fay, R.O., 1967, Phylogeny and evolution, in Moore, R.C., ed., Treatise on Invertebrate Paleontology, Pt. S, Echinodermata 1, v. 2: New York and Lawrence, Geological Society of America and University of Kansas, p. S392-S396.

Foote, M., 1991, Morphological and taxonomic diversity in a clade's history: The blastoid record and stochastic simulations: University of Michigan Museum of Paleontology Contributions, v. 28, p. 101-140.

Galloway, J.J., and Kaska, H.V., 1957, Genus Pentremites and its species: Geological Society of America Memoirs, v. 69, p. 1-114.

Goldfuss, G.A., 1826-1844, Petrefacta Germaniae: Theil I: Düsseldorf, Arnz \& Co., $252 \mathrm{p}$.

Hall, J., 1858, Palaeontology of Iowa: Iowa Geological Survey Report, v. 1, pt. 2, Palaeontology, p. 473-724

Hambach, G., 1903, Revision of the Blastoidea, with a proposed new classification, and description of new species: Transactions of the Academy of Science of St. Louis, v. 13, p. 40.

Huynh, T.L., Evangelista, D., and Marshall, C.R., 2015, Visualizing the fluid flow through the complex skeletonized respiratory structures of a blastoid echinoderm: Palaeontologia Electronica, v. 18, p. 1-17.

Jaekel, O., 1918, Phylogenie und system der pelmatozoen: Palaeontologische Zeitschrift, v. 3, p. 1-128.

Jansen, H., 1934, Die Variationsstatistische Methode angewandt auf ein grosses Material von Schizoblastus aus dem Perm von Timor und einige neue Anomalien dieser Gattung: Koninklijke Akademie van Wetenschappen te Amsterdam, v. 37, no. 10, p. 819-825.

Joysey, K.A., 1959, A study on the variation and relative growth in the blastoid Orbitremites: Philosophical Transactions of the Royal Society of London, Series B, Biological Sciences, v. 242, no. 68, p. 99-125.

Kammer, T.W., Sumrall, C.D., Zamora, S., Ausich, W.I., and Deline, B., 2013, Oral region homologies in Paleozoic crinoids and other plesiomorphic pentaradial echinoderms: PLoS ONE, v. 8, e77989, doi: 10.1371/journal pone. 0077989 .

Katz, S.G., and Sprinkle, J., 1976, Fossilized eggs in a Pennsylvanian blastoid: Science, v. 192, p. 1137-1139.

Katz, S.G., and Sprinkle, J., 1977, Morrowan (Lower Pennsylvanian) Pentremites in Oklahoma and Arkansas, in Sutherland, P.K., and Manger, W.L., eds., Upper Chesterian-Morrowan Stratigraphy and the Mississippian-Pennsylvanian Boundary in Northeastern Oklahoma and Northwestern Arkansas: Oklahoma Geological Survey Guidebook, v. 18, p. 161-166.

Keyes, R.R., 1894, Paleontology of Missouri: Jefferson City, Missouri Geological Survey, $271 \mathrm{p}$.

Leighton, L.R., and Maples, C.G., 2002, Evaluating internal versus external characters: Phylogenetic analyses of the Echinoconchidae, Buxtoniinae, and Juresaniinae (Phylum Brachiopoda): Journal of Paleontology, v. 76, p. 659-671.

Macurda, D.B., Jr., 1967, The lower Carboniferous (Tournaisian) blastoids of Belgium: Journal of Paleontology, v. 41, p. 455-486.

Macurda, D.B., Jr., 1969, Blastoids, in McKee, E.D., and Gutschick, R.C., eds., The history of the Redwall Limestone of northern Arizona: Geological Society of America Memoir v. 114, p. 457-473.
Macurda, D.B., Jr., 1973, The stereomic microstructure of the blastoid endoskeleton: University of Michigan Museum of Paleontology Contributions, v. 24, p. 69-83. Macurda, D.B., Jr., 1975, The Pentremites (Blastoidea) of the Burlington Limestone (Mississippian): Journal of Paleontology, v. 49, p. 346-373.

Macurda, D.B., Jr., 1983, Systematics of the fissiculate Blastoidea: University of Michigan, Museum of Paleontology, Papers on Paleontology, v. 22, 291 p.

Macurda, D.B., Jr., and Breimer, A., 1977, Strongyloblastus, a Mississippian blastoid from Western Canada: Journal of Paleontology, v. 51, p. 693-700.

Meek, F.B., and Worthen, A.H., 1869, Remarks on the Blastoidea with descriptions of new species: Journal of the Academy of Natural Sciences Philadelphia, v. 21, p. 335-359.

Meek, F.B., and Worthen, A.H., 1873, Descriptions of invertebrates from Carboniferous system: Illinois Geological Survey, v. 5, pt. 2, p. 320-619.

Owen, D.D., and Shumard, B.F., 1850, Descriptions of fifteen new species of Crinoidea from the sub-Carboniferous limestone of Iowa, collected during the U.S. Geological Survey of Wisconsin, Iowa, and Minnesota in the years 1848-1849: Journal of the Academy of Natural Sciences Philadelphia, new series, v. 2, pt. 1, p. $57-70$

Paul, C.R.C., 1968, Morphology and function of dichoporite pore-structures in cystoids: Palaeontology, v. 11, p. 697-730.

Paul, C.R.C., 1972, Morphology and function of exothecal pore-structures in cystoids: Palaeontology, v. 15, p. 1-28.

Rahman, I.A., and Zamora, S., 2009, The oldest cinctan carpoid (stem-group Echinodermata), and the evolution of the water vascular system: Zoological Journal of the Linnean Society, v. 157, p. 420-432.

Rahman, I.A., Waters, J.A., Sumrall, C.D., and Astolfo, A., 2015, Early post-metamorphic, Carboniferous blastoid reveals the evolution and development of the digestive system in echinoderms: Biology Letters, v. 11, 2015776 10.1098/rsbl.2015.0776.

Roemer, C.F., 1851, Monographie der fossilen Crinoiden-familie der Blastoideen, und der Gattung Pentatrematites in Besondern: Archiv füir Nature-geschichte, 17, v. 1, no. 3, p. 323-397.

Say, T., 1820, Observations on some species of Zoophytes and shells principally fossil: American Journal of Science, v. 2, p. 34-45.

Say, T., 1825, On two genera and several species of Crinoidea: Journal of the Academy of Natural Sciences Philadelphia, 1st Series, v. 4, p. 289-296.

Schmidtling, R.C., and Marshall, C.R., II, 2010, Three dimensional structure and fluid flow through the hydrospires of the blastoid echinoderm, Pentremites rusticus: Journal of Paleontology, v. 84, p. 109-117.

Shumard, B.F., 1863, Decriptions of new Palaeozoic fossils: Transactions of the Academy of Science of : St. Louis, v. 1, p. 71-80.

Sowerby, G.B., 1825, Note on the foregoing paper, together with a description of a new species of Pentremities: Zoological Journal, v. 2, p. 316-318.

Sprinkle, J., 1973, Morphology and Evolution of Blastozoan Echinoderms: Harvard University, Museum of Comparative Zoology Special Publication, $283 \mathrm{p}$.

Sprinkle, J., and Sumrall, C.D., 2008, New parablastoids from the western United States: University of Kansas Paleontological Contributions, New Series no. 16, p. 1-14.

Sumrall, C.D., 2010, A model for elemental homology for the peristome and ambulacra in blastozoan echinoderms, in Harris, L.G., Böttger, S.A., Walker, C.W., and Lesser, M.P., eds., Echinoderms: Durham: London, CRC Press, p. 269-276.

Sumrall, C.D., and Waters, J.A., 2012, Universal elemental homology in glyptocystitoids, hemicosmitoids, coronoids and blastoids: Steps toward echinoderm phylogenetic reconstruction in derived Blastozoa: Journal of Paleontology, v. 86, p. 956-972.

Swofford, D.L., 2003, PAUP* Version 4.0.b10: Phylogenetic analysis using parsimony and other methods: Sunderland, Massachusetts, Sinauer Associates.

Ulrich, E.O., 1917, The formations of the Chester series in western Kentucky and their correlates elsewhere: Lexington, Kentucky Geological Survey, 272 p

von Schlotheim, E.F., 1821, Die Petrefactenkunde: Gotha, Becker, 339 p.

Wanner, J., 1910, Über eine merkwürdige Echinodermenform aus dem Perm von Timor: Zeitschrift fur inductive Abstammungs-und Vererbungslehre, v. 4 , p. $123-142$.

Wanner, J., 1924, Die permischen Echinodermen von Timor, II: Teil, Palaeontologie von Timor, v. 14, p. 199-206.

Wanner, J., 1932, Neue Beiträge zur Kentniss der Permischen Echinodermen von Timor, VII, Die Anomalieen der Schizoblastsen: Wetenschappelijke Mededeelingen, Dienst van den Mijnbouw In Nederlands-Oost-Indie, no. 20 , p. $1-46$

Wanner, J., 1940, Neue Blastoideen aus dem Perm von Timor (mit einem Beitrag zur Systematik der Blastoideen): Geological Expedition of the University of Amsterdam to the Lesser Sunda Islands in the South-Eastern Part of the Netherlands East Indies, v. 1, p. 220-276.

Waters, J.A., 1988, The evolutionary palaeoecology of the Blastoidea, in Paul, C.R.C., and Smith, A.B., eds., Echinoderm Phylogeny and Evolutionary Biology: Oxford, Clarendon Press, p. 215-233. 
Waters, J.A., 1990, The paleobiogeography of the Blastoidea (Echinodermata), in McKerrow, W.S., and Scotese, C.R., eds., Palaeozoic Palaeogeography and Biogeography: Geological Society of London, Memoir 12, p. 339-352.

Waters, J.A., and Horowitz, A.S., 1993, Ordinal-level evolution in the Blastoidea: Lethaia, v. 26, p. 207-213.

Waters, J.A., Rahman, I.A., Sumrall, C.D., White, L.E., and Nguyen, B.K., 2014, Acetate peels and synchrotron imaging reveal the internal anatomy of blastoids (Echinodermata): Geological Society of America Abstracts with Programs, v. 46, p. 138.

Waters, J.A., Sumrall, C.D., White, L.E., and Nguyen, B.K., 2015, Advancing phylogenetic inference in the Blastoidea (Echinodermata): Virtual 3D reconstructions of the internal anatomy, in Zamora, S., and Rábano, I., eds., Progress in Echinoderm Palaeobiology: Cuadernos del Museo Geominero, 19. Instituto Geológico y Minero de España, Madrid, p. 193-197.

Waters, J.A., White, L.E., Sumrall, C.D., and Nguyen, B.K., 2017, A new model of respiration in blastoid (Echinodermata) hydrospires based on CFD simulations of virtual 3D models: Journal of Paleontology, https://doi.org/ 10.1017/jpa.2017.1.
Weller, S., 1898, A bibliographic index of North American Carboniferous invertebrates: U.S. Geological Survey Bulletin 153, 653 p.

Weller, S., 1920, The geology of Hardin County: Illinois Geological Survey, Bulletin 41, $416 \mathrm{p}$.

White, C.A., 1881, Fossils of the Indiana Rocks: 2nd Annual Report, Indiana Department of Statistics and Geology, 1880, p. 511-512.

Wright, D.F., and Stigall, A.L., 2013, Phylogenetic revision of the Late Ordovician orthid brachiopod genera Plaesiomys and Hebertella from North America: Journal of Paleontology, v. 87, p. 1107-1128.

Wright, D.F., and Stigall, A.L., 2014, Species-level phylogenetic revision of the orthide brachiopod Glyptorthis from North America: Journal of Systematic Paleontology, v. 12, p. 893-906.

Accepted 16 February 2017 